Ткаченко В. А., канд. військ. наук

$(0000-0002-9625-2434)$

Центр воєнно-стратегічних досліджень Національного університету оборони України імені Івана Черняховського, Київ

\title{
Інформаційний вплив як вид інформаційного забезпечення в Міністерстві оборони України та Збройних Силах України
}

Резюме. У статті проведено аналіз сутності інформаційного впливу як виду інформаційного забезпечення системи державного управління у військовій сфері, зокрема в Міністерстві оборони України та ії Збройних Силах.

Ключові слова: державне управління; інформаційне забезпечення системи державного управління в Міністерстві оборони України та Збройних Силах України; інформаційний вплив; інформаційнопсихологічний вплив.

Постановка проблеми. Відповідно до основних вимог (принципів) кібернетики для досягнення цілей державного управління, зокрема у військовій сфері, має бути створена ефективна система управління у складі таких елементів [1-3]: органу державного управління, який генерує політику та ідеї державного управління; виконавчого органу, що здійснює практичні заходи управлінського впливу; об'єкта управління (впливу) та органу державного моніторингу (контролю) результатів державного управління (дій або стану об'єкта управління). Така система потребує наявності інформаційного забезпечення на усіх іiі рівнях. Причиною цього $€$ те, що всі структурні елементи системи державного управління як соціальної системи пов'язані із відповідним персоналом (у військовій сфері - 3 особовим складом). Тому в процесі функціонування системи державного управління між суб'єктами обов'язково існують відносини, які відбуваються шляхом реалізації відповідних інформаційних процесів.

У таких процесах інформаційний вплив розглядається як окремий вид інформаційного забезпечення системи державного управління. На усіх рівнях такої системи якість зазначеного впливу суттево впливає на іï загальну ефективність функціонування. Оскільки система, що розглядається, $\epsilon$ системою соціального управління, то увага зосереджується на інформаційно-психологічному впливі як різновиді інформаційного впливу з урахуванням специфіки та особливостей управління у військовій сфері, зокрема в Міністерстві оборони України (МО України) та Збройних Силах України (ЗС України). На сьогодні теоретичний аспект цього питання розкритий недостатньо, що потребує окремого дослідження.

Аналіз останніх досліджень i публікацій. Нині стан науки державного управління характеризується активним розвитком його теоретичних засад. Про це свідчать численні публікації в наукових i публіцистичних виданнях. Відомі вчені В. Цвєтков [4], Ю. Ковбасюк [5], Ю. Сурмін [5], К. Ващенко [5], В. Князєв [6], В. Бакуменко [6], П. Надолішній [7], а у військовій сфері I. Руснак [8], В. Телелим [8], В. Толубко [9] та інші, у своїх публікаціях приділяли певну увагу питанням розвитку системи державного управління.

Водночас, питання інформаційного забезпечення системи державного управління, зокрема, у військовій сфері, в теоретичному плані в Україні досі не опрацьоване. Уперше це питання розглянуто в роботі П. Сніцаренка i В. Новосьолова [10]. Останнім часом цій темі присвячені роботи П. Сніцаренка, Ю. Саричева та О. Устименка [1-3, 11-15], де значна увага приділяється саме питанням інформаційного забезпечення системи державного управління, зокрема й у військовій сфері. У цих роботах визначено, що інформаційний вплив є одним із видів інформаційного забезпечення системи державного управління 3 його різновидом інформаційно-психологічним впливом. Такий різновид інформаційного впливу безпосередньо пов'язаний 3 людиною - носієм інформації, тому він $є$ невід'ємною складовою загального процесу інформаційного забезпечення системи державного управління, зокрема в МО України та ЗС України.

Питання визначення сутності, ролі та місця інформаційно-психологічного впливу як різновиду інформаційного впливу в процесі інформаційного забезпечення в системі державного управління, зокрема i в МО України та ЗС, залишається недостатньо висвітленим, отже, воно є актуальним для дослідження. 
Метою статті $€$ визначення сутності, ролі та місця інформаційно-психологічного впливу (як різновиду інформаційного впливу) в загальному процесі інформаційного забезпечення в МО України та ЗС України.

Викладення основного матеріалу. Відповідно до Конституції та законів України державне управління у військовій сфері, зокрема стосовно МО України та їі 3С, має за мету організацію i виконання комплексу заходів підготовки держави до оборони (в мирний час) та ведення оборони держави (у разі збройної агресії проти неї) [1-3]. На цім під системою державного управління $у$ воєнній сфері необхідно розуміти організовану сукупність елементів (органу державного управління, виконавчого органу, об'єкта управління (впливу) та органу моніторингу), об'єднаних між собою цільовими функціями управління. За законами кібернетики будь-яка функція управління реалізується виключно інформаційним шляхом, а тому очевидно, що процес державного управління, зокрема стосовно МО України та ЗС України, потребує реалізації низки інформаційних процесів, що справляють вплив на усі елементи системи державного управління у військовій сфері. Сукупність цих інформаційних процесів власне і об'єднується поняттям інформаиійного забезпечення, яке пронизує весь замкнений контур державного управління, а його сутність полягає, 3 одного боку, у необхідності формування ідеї, мети і завдань державного управління та їх донесення від органу державного (військового) управління до елементів системи шляхом реалізації комплексу організуючих інформаційних процесів, а з іншого - у можливості отримання органом державного управління зворотної інформації для контролю процесу управління та його коригування.

Аналіз показує, що реалізація усього процесу державного управління за кібернетичною схемою потребує саме комплексного підходу до виконання різнорідних функцій інформаційного забезпечення на усіх рівнях та етапах державного управління у військовій сфері, зокрема для МО України та ЗС України. Це дає змогу зробити акцент на необхідності розгляду усіх складових інформаційного забезпечення, зокрема тієї складової, що пов'язана 3 інформаційно-психологічним впливом як різновидом інформаційного впливу в системі державного управління стосовно МО України та ЗС України.
Відповідно до [11] інформачійнопсихологічний вплив - цілеспрямоване інформаційне втручання у свідомість (підсвідомість) цільової аудиторії 3 метою корекції іiі поведінки та (або) світогляду, зміни морально-психологічного стану. Засобами інформаційно-психологічного впливу $є$ ЗМІ, спеціальна друкована продукція, публічна голосова агітація, агентурна діяльність, спеціальні інформаційні технології тощо.

Загалом, інформаційно-психологічний вплив, який може бути як позитивним, так i негативним, здійснюється у формі кампаній, операцій, акцій, атак та окремих актів, що можуть реалізовуватися як самостійні заходи (діi) [11]. Такі заходи можуть проводитися як у мирний час, так і в особливий період.

Найважливішою умовою перемоги в сучасних війнах (збройних конфліктах) $\epsilon$ завоювання переваги в інформаційній сфері, зокрема 3 наслідком переваги в моральнопсихологічному стані власних військ над військами противника. Перевага в моральнопсихологічному відношенні досягається, насамперед, завдяки більш ефективним заходам здійснення інформаційнопсихологічного впливу на власні війська та війська противника.

Загалом, як у мирний час, так i в особливий період (воєнний час) метою здійснення негативного інформаційнопсихологічного впливу 3 боку кожної із протидіючих сторін на особовий склад військ (сил) $є$ погіршення морально-психологічного стану особового складу військ (сил) супротивної сторони (противника), що $є$ необхідною умовою зниження їх психологічної готовності до діяльності або відмови іiі здійснювати. Зважаючи на специфіку функціонування системи державного управління у військовій сфері, зокрема щодо МО України та ЗС України, усі елементи якої пов'язані з організацією і проведенням заходів підготовки держави до оборони та ведення оборони держави у разі збройної агресії проти неї, $\epsilon$ необхідність розглянути особливості здійснення інформаційно-психологічного впливу на власні війська і населення як в мирний час, так і в особливий період (воєнний час), а також специфіку такого впливу на війська та населення недружніх держав (противника). До того ж необхідно враховувати, що в першому випадку об'єктом державного управління має бути результативність заходів підготовки держави до оборони (рівень набуття необхідних спроможностей сил оборони), а у другому результативність заходів ведення оборони 
держави у разі збройної агресії проти неї (рівень підготовки та результат ведення операцій i бойових дій сил оборони проти агресора), і в обох випадках реалізуються заходи інформаційно-психологічного впливу 3 урахуванням певних особливостей.

Слід зауважити, що загалом інформаційно-психологічний вплив можна поділити за напрямами:

внутрішнього спрямування - метою $\mathrm{\epsilon}$ зміцнення морально-психологічного стану своїх військ та населення, а також захист їх від негативного інформаційно-психологічного впливу противника та нейтралізація наслідків такого впливу;

зовнішнього спрямування - метою $є$ посилення в уряді країни чи блоку країн, населення, у військового командування та особового складу військових частин інших держав сумнівів у правоті їх власних дій, деморалізація та дезорганізація їх діяльності, а також покращення міжнародного політичного іміджу власної держави та своїх збройних сил.

Основними завданнями інформаційнопсихологічного впливу мирного часу на визначені цільові аудиторії є такі [15].

Внутрішнього спрямування:

стабілізація суспільно-політичної обстановки у власній державі;

зміцнення моральних зв'язків народу i армї;

покращення політичного клімату між політичними силами;

недопущення створення передумов соціального вибуху у воєнній складовій власного інформаційного простору.

Зовнішнього спрямування:

здійснення впливу в інформаційному просторі недружньої держави для створення сумнівів законності дій керівництва їх країни та їх збройних сил стосовно нашої держави;

поліпшення міжнародного політичного іміджу власної держави та своїх збройних сил.

Основними завданнями інформаційнопсихологічного впливу в особливий період (воєнний час) на визначені цільової аудиторії $\epsilon$ такі [15].

Внутрішнього спрямування:

укріплення морально-психологічного стану своїх військ;

внесення злагоди між армією, народом $\mathrm{i}$ владою власної держави;

локалізація опозиції власної держави, зокрема стосовно їі збройних сил;

інформування різних цільових аудиторій для створення позитивного іміджу власних збройних сил.
Зовнішнього спрямування:

дестабілізація суспільно-політичної обстановки в державі (коаліції держав) супротивної сторони; підрив морально-психологічного стану військ противника та його населення; внесення розбрату між армією, народом і владою супротивної сторони; підтримка опозиції супротивної сторони; підбурювання до непокори владі противника; поліпшення міжнародного політичного іміджу власної держави.

Загалом, негативний інформаційнопсихологічний вплив з боку противника несе загрозу функціонуванню системи державного управління у військовій сфері, особливо у частині іiі інформаційного забезпечення через вплив (тиск) на ii збройні сили. Зазначений процес більш характерний для особливого періоду, коли інформаційно-психологічний вплив противника $\epsilon$ реальним явищем. Для періоду мирного часу необхідно проводити упереджувальні заходи протидії на основі моніторингу інформаційного простору військової сфери, коли явища впливу ще немає, але є ситуація можливого виявлення викликів i загроз щодо зовнішнього інформаційно-психологічного впливу на особовий склад військ (сил) та органи військового управління. Такі упереджувальні заходи протидії $є$ захистом від негативного інформаційно-психологічного впливу, коли зусилля спрямовані на власну аудиторію [9].

Захист від негативного інформаичийнопсихологічного впливу противника цілеспрямований комплекс заходів, що проводяться в мирний час та особливий період органами управління та іншими посадовими особами щодо попередження, виявлення, нейтралізації (послаблення), блокування та ліквідації наслідків (зведення до мінімуму) негативного інформаційно-психологічного впливу противника на військовослужбовців, цивільний персонал і населення [11].

Для дієвого захисту від негативного інформаційно-психологічного впливу в системі державного (військового) управління необхідно мати певний державний механізм підсистему протидії негативному інформаційно-психологічному впливу на особовий склад військ (сил), яка здатна ефективно функціонувати в сучасних умовах 3 урахуванням загального принципу державного управління у військовій сфері. Отже для збройних сил запропоновано загальну 
кібернетичну схему (модель) протидії впливу на особовий склад військ (сил), яка негативному інформаційно-психологічному наведена на рис. 1.

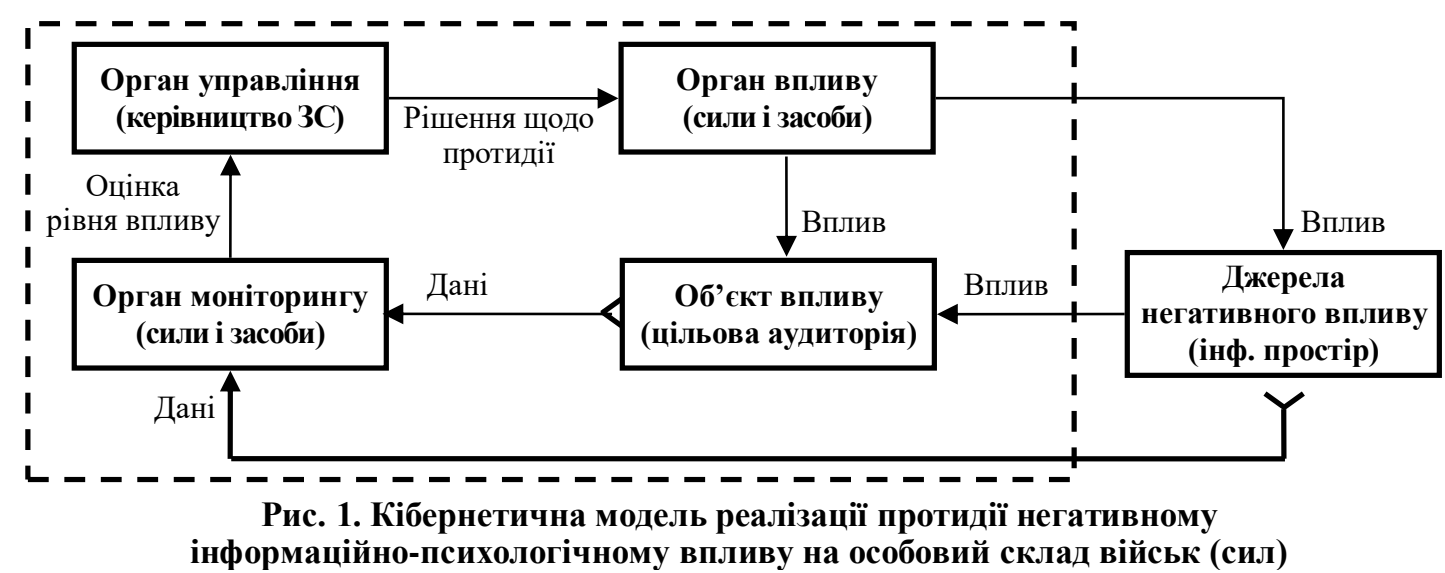

Наведена модель може найбільш повно забезпечити активну протидію негативному інформаційно-психологічному впливу на особовий склад військ (сил), як зазначено в [15], з такими іï обов'язковими фазами:

виявлення впливу;

оцінювання рівня впливу;

формування висновків 3 оцінки рівня впливу та рішення щодо необхідності протидії;

планування заходів протидії впливу, затвердження плану заходів протидії;

реалізація заходів протидії впливу відповідно до плану;

контроль дієвості реалізованих заходів протидії впливу та їх коригування.

Це означає, що $\mathrm{i}$ в мирний час (в особливий період), і під час застосування сил оборони держави у воєнний час, для забезпечення сприятливих умов виконання завдань військами (силами) в системі державного управління у військовій сфері силами такої підсистеми мають проводитися заходи протидії зовнішньому і внутрішньому негативному інформаційно-психологічному впливу. Така протидія включає цілеспрямовані дії структурних підрозділів МО України, Генерального штабу (ГШ) 3С України та інших органів державного військового управління у взаємодії з органами управління та структурними підрозділами інших складових сил оборони щодо виявлення джерел (носіїв) інформаційно-психологічного впливу, проведення заходів для його нейтралізації, а також здійснення інформаційно-психологічного впливу на противника.

Особливості функціонування існуючої підсистеми протидії негативному інформаційно-психологічному впливу полягають у наявності в структурах
МО України та ЗС України, інших складових сил оборони підрозділів 3 функціями, завданнями і можливостями щодо проведення заходів такої протидії та організації відповідної діяльності.

У МО України структурними підрозділами, які безпосередньо причетні до протидії негативному інформаційнопсихологічному впливу, здійснюється [16]:

розвідувальна та інформаційноаналітична діяльність в інтересах національної безпеки та оборони держави;

аналіз воєнно-політичної обстановки та визначається рівень воєнної загрози національній безпеці;

виконання заходів, спрямованих на підтримку національних інтересів і державної політики України у військовій сфері;

виконання заходів щодо протидії i нейтралізації воєнно-політичних ризиків, викликів, загроз застосування воєнної сили проти України;

здійснення моніторингу інформаційного середовища, виявлення потенційних та реальних інформаційних загроз в оборонній сфері, проведення попереджувальних інформаційних заходів;

формування та організація реалізації єдиної інформаційної політики в МО України; створення інформаційного середовища МО України, його інтеграція до інформаційних систем та ресурсів органів державної влади;

створення та розвиток інформаційної інфраструктури за компонентами інформаційного середовища МО України;

координація організаційних заходів щодо формування єдиного інформаційного простору, впровадження космічних інформаційних технологій; 
організація функціонування системи забезпечення інформаційної безпеки у МО України;

впровадження новітніх інформаційних технологій, створення та розвиток інформаційних систем і ресурсів, спрямованих на підвищення оперативності та ефективності прийняття управлінських рішень у сфері оборони;

реалізація єдиної стратегії у МО України відповідно до засад державної політики 3 інформаційної безпеки та інформатизації;

інформування громадськості та 3МІ про діяльність МО України та ЗС України;

морально-психологічне забезпечення підготовки та ведення операцій (бойових дій), метою якого $\epsilon$ формування та підтримка морально-психологічного стану особового складу, бойових і психологічних якостей, необхідних для успішного виконання бойових завдань, однією складовою якого є захист від негативного інформаційно-психологічного впливу;

координація діяльності структурних підрозділів МО України та організація взаємодії у встановленому порядку зі структурними підрозділами ГШ ЗС України, центральними органами виконавчої влади, органами військового управління інших складових сектору безпеки і оборони під час вирішення завдань із забезпечення інформаційної безпеки (зокрема кібербезпеки).

У ГШ ЗС України структурними підрозділами, які причетні до сфери протидії негативному інформаційно-психологічному впливу, може здійснюватися [17]:

залучення органів управління та військових частин розвідки ЗС України до заходів добування відповідної розвідувальної інформації;

участь в аналізі та оцінюванні рівня загроз національній безпеці в інформаційній сфері та підготовка пропозицій щодо протидії їм;

організація планування спеціальних, інформаційних (у т. ч. кібер-) операцій ЗС України та інших складових сил оборони;

організація та координація заходів радіоелектронної боротьби (РЕБ) та радіоелектронної протидії в інтересах застосування 3С України;

проведення заходів щодо виділення оптимального радіочастотного ресурсу силам $\mathrm{i}$ засобам своїх військ для здійснення інформаційного (інформаційно- психологічного) впливу на визначену цільову аудиторію;

взаємодія зі структурними підрозділами MO України, інших центральних органів виконавчої влади, а також органів управління та структурних підрозділів сектору безпеки i оборони 3 питань організації інформаційної боротьби;

організаційна та координаційна робота щодо реалізації технічних і програмних методів захисту електронних інформаційних ресурсів та функціонування інформаційнотелекомунікаційних систем (мереж) МО України, 3С України та інших органів військового управління;

управління процесом ведення інформаційно-психологічних дій, зокрема протидії негативному інформаційнопсихологічному впливу на особовий склад військ (сил);

проведення заходів моніторингу інформаційного простору держави для виявлення та оцінювання інформаційного, інформаційно-психологічного

кібернетичного впливу на інформаційне середовище та відповідної протидії;

забезпечення у взаємодії з Державною службою спеціального зв'язку та захисту інформації України та Службою безпеки України кіберзахист інформаційної інфраструктури МО України і ЗС України;

розроблення пропозицій щодо удосконалення нормативно-правової бази та напрямів розвитку теоретичних основ інформаційної боротьби.

Крім того, у складі органів військового управління, видів, родів військ (сил) ЗС України $\epsilon$ певні сили та засоби, які здатні здійснювати заходи протидії негативному інформаційнопсихологічному впливу на особовий склад військ (сил).

Отже, на підставі викладеного та 3 урахуванням [12-14] для МО України та ЗС України пропонується таке визначення: nid інформачійно-психологічним впливом (у МО України та іï ЗС) слід розуміти вид інформаційного забезпечення діяльності суб'єктів військових формувань держави як організований комплекс заходів, що реалізують процеси цілеспрямованого інформаційного (негативного чи позитивного) втручання у свідомість (підсвідомість) чи фізичний стан особового складу та керівництва МО України та ЗС України, інших цільових аудиторій для корекції їх поведінки та (або) світогляду, зміни морально-психологічного стану.

Запропоноване

визначення 
інформаційно-психологічного впливу як виду інформаційного забезпечення системи державного управління стосовно МО України та ЗС України відображає інформаційну функцію цілеспрямованого інформаційного впливу на визначені цільові аудиторії протиборчих сторін. Роль інформаційнопсихологічного впливу як виду інформаційного забезпечення в системі державного управління в МО України та ЗС України полягає в інформаційному втручанні у свідомість (підсвідомість) керівного та особового складу військ і населення:

а) власної держави - 3 метою підтримки їх психічного стану, захисту і реабілітації;

б) супротивної недружньої сторони - 3 метою внесення змін у поведінку та (або) світогляд, які підривають їх моральнопсихологічний стан.

Отже, в Україні існують основні складові національної системи державного управління у військовій сфері, зокрема в МО України та ЗС України здатні здійснювати, зокрема, протидію негативному інформаційнопсихологічному впливу на особовий склад військ (сил) та населення держави. МО України, ГШ ЗС України, органи військового управління видів, родів військ (сил) ЗС України мають доволі значний структурний i технічний потенціал для проведення інформаційно-психологічних дій (операцій, акцій), зокрема в інтересах протидії негативному інформаційно-психологічному впливу на особовий склад органів управління, військ (сил) та населення держави. Водночас, існуюча система та іï частина, яка має протидіяти негативному інформаційнопсихологічному впливу на особовий склад органів військового управління, військ (сил) ЗС України, відповідних органів управління та структурних підрозділів інших складових сил оборони, потребує подальшого удосконалення.

\section{Висновки:}

1. Інформаційний вплив необхідно розглядати як невід'ємну складову державного управління для МО України та ЗС України. Усі складові у сукупності мають забезпечити збалансоване та ефективне функціонування єдиної системи державного управління, зокрема стосовно МО України та ЗС України.

2. Під інформаційним впливом (в МОУкраїни та іï ЗС) слід розуміти вид інформаційного забезпечення діяльності суб'єктів військових формувань держави як організований комплекс заходів, що реалізують процеси цілеспрямованого інформаційного втручання у свідомість (підсвідомість) чи фізичний стан осіб певної цільової аудиторії $з$ метою корекції іiі поведінки та (або) світогляду, зміни морально-психологічного стану.

3. Роль інформаційно-психологічного впливу системи державного управління в MO України та ЗС України полягає в інформаційному втручанні у свідомість (підсвідомість) керівного та особового складу військ і населення: а) власної держави - 3 метою підтримки їх психічного стану, захисту і реабілітації; б) противника - 3 метою внесення змін у поведінку та (або) світогляд, які підривають їх морально-психологічний стан. Місце інформаційно-психологічного впливу визначається характером завдання, що виконується не лише на рівні органу управління, а в кожній ланці всього кібернетичного контуру державного управління у військовій сфері.

Подальші дослідження. Для підвищення ефективності застосування усіх сил та засобів, які за єдиним задумом і планом можуть бути безпосередньо залучені до сфери протидії негативному інформаційно-психологічному впливу, вважається за доцільне зосередити зусилля на дослідженні питання щодо створення повноважного об'єднаного орган керівництва 3 протидії негативному інформаційнопсихологічному впливу в Україні, що дасть змогу підвищити ефективність процесу державного управління, зокрема в МО України та ЗС України.

Окремого дослідження потребують також питання удосконалення нормативноправової бази держави інформаційного спрямування, яка має регламентувати усі можливі аспекти інформаційно-психологічної протидії, а також особливості застосування різних механізмів здійснення негативного інформаційно-психологічного впливу як на окремих осіб, що приймають рішення, так i масові цільові аудиторії.

\section{СПИСОК ВИКОРИСТАНОЇ ЛІТЕРАТУРИ}

1. Устименко О. В., Сніцаренко П. М., Саричев Ю. О. Державне управління у воєнній сфері як об'єкт термінології та практичної діяльності. Збірник наукових праџь НАДУ при Президентові України / за заг. ред. А.П. Савкова. Київ, 2019. Вип № 1. С.6974.

2. Сніцаренко П. М., Саричев Ю. О., Зубков В. П., Устименко О. В. Система державного управління у воєнній сфері при підготовці держави до оборони: сутність та особливості. Науковий часопис Академії національної безпеки. Київ, 2019. № 1-2 (21-22). C.95-107.

3. Саричев Ю. О., Устименко О. В., Сніцаренко П. М. 
Сутність та особливості системи державного управління у воєнній сфері при підготовці держави до оборони. Вісник Національної академії при Президентові України. Київ, 2019. Вип. № 3 (97). C.47-52.

4. Цвєтков В. В. Державне управління як основний різновид соціального управління. Реформування державного управління в Україні: проблеми i перспективи / кол. авт.; наук. кер. В.В. Цвєтков. Київ: Оріяни, 1998. С.17-37.

5. Державне управління: підручник : у 2 т. / редкол. : Ю. В. Ковбасюк (голова), К. О. Ващенко (заст. голови), Ю. П. Сурмін (заст. голови) та ін. Київ; Дніпропетровськ : НАДУ, 2012. Т. 1. 564 с.

6. Державне управління: словник-довідник / за заг. ред. В. Д. Бакуменка, В. М. Князєва. Київ : УАДУ, 2002. $228 \mathrm{c}$.

7. Надолішній П. І. Теорія та історія державного управління (опорний конспект лекцій до навчальної дисципліни) : навч. посіб. Одеса : ОРІДУ НАДУ, 2006. $126 \mathrm{c}$.

8. Руснак I. С., Телелим В. М. Розвиток форм i способів інформаційної боротьби на сучасному етапі. Наука і оборона. 2000. № 2. С.18-23.

9. Інформаційна безпека держави у контексті протидії інформаційним війнам: навчальний посібник / за ред. В. Б. Толубка. Київ: НАОУ, 2004. 315 с.

10. Новосьолов В. В., Сніцаренко П. М. Концептуальні погляди на інформаційне забезпечення органів реагування України в кризових ситуаціях воєнного характеру. Національна безпека: украӥнський вимір. Київ, 2010. Вип. 7 (26). С.75-80.

11. ВСТ 01.004 .004 - 2014 (01). Інформаційна безпека держави у воєнній сфері. Терміни та визначення. [Чинний від 2014-02-27]. Вид. офіц. Київ : НУОУ, 2014. 24 с. (Військовий стандарт).

12. Сніцаренко П. М., Саричев Ю. О. Теоретичні підходи до визначення сутності інформаційного забезпечення в системі державного управління. Науково-інформаційний вісник Академії національної безпеки. Київ, 2016. № 1-2 (9-10).
C. 7-19.

13. Саричев Ю. О. Аналіз підходів щодо визначення сучасної ролі та місця інформаційного забезпечення в системі державного управління. Вісник Начіональної академії державного управління при Президентові Украӥни. Державне управління. Київ, 2016. Вип. 3 (82). С.138-143.

14. Саричев Ю. О. Теоретичний підхід до інформаційного забезпечення в системі державного управління у воєнній сфері. Вісник Національної академії державного управління при Президентові України. Державне управління. Київ, 2016. Вип. 4 (83). C.153-160.

15. Аналіз існуючої системи протидії негативному інформаційно-психологічному впливу на особовий склад військ (сил) та органи військового управління, шифр “Система-Р” : звіт (проміжний) виконання НДР. Київ : НУОУ, 2013. 113 с.

16. Про внесення змін до Положення про Міністерство оборони України : Постанова Кабінету Міністрів України від 26.11.2014 р. № 671 (у редакції постанови Кабінету Міністрів України від 19.10 .2016 p. № 730). URL: https://zakon.rada. gov.ua/laws/show/730-2016-п\#Text (дата звернення: 01.09.2019).

17. Про Положення про Генеральний штаб Збройних Сил України : Указ Президента України від 30.01.2019 p. № 23/2019. URL: https://www.president. gov.ua/dokuments/232019-25974. (дата звернення: 01.09.2019).

18. Про оборону України : Закон України від 06.12.1991 p. № 1932-XII . URL: https://zakon.rada. gov.ua/laws/show/1932-12 (дата звернення: 01.09.2019).

19. Про рішення Ради національної безпеки і оборони України від 29 грудня 2016 року "Про Доктрину інформаційної безпеки України” : Указ Президента України від 25.02.2017 p. № 47/2017. URL: https://zakon.rada. gov.ua/laws/show/47/ 2017\#Text (дата звернення: 01.09.2019).

\section{Стаття надійшла до редакційної колегії 12.01.2020}

\section{Information impact as a type of information support in the Ministry of Defense of Ukraine and the Armed Forces of \\ Ukraine}

\section{Annotation}

The article analyzes information influence as a type of information support of the public administration system in the military sphere, particularly in the Ministry of Defense and Armed Forces of Ukraine. At the same time, public administration is proposed to be considered as a complex cybernetic process with many components. In this process, the system of public administration in the military sphere is not departmental, but national in nature. In this process, the main elements of such a system are the components, which by their informational nature implement the full list of functions of public administration in the military sphere, in particular in the Ministry of Defense of Ukraine and the Armed Forces of Ukraine. One of such components is informational influence. The main emphasis in the article is on the information-psychological variety of such influence. Based on the analysis of the current structure of the system, the author offers his vision of approaches to the consideration of information-psychological impact. Such influence is an integral part of the information support of the public administration system in the military sphere, in particular in the Ministry of Defense of Ukraine and its Armed Forces. Based on the refined definition of this concept, its role and place in such a system are substantiated. At the same time, the role of information-psychological influence of the public administration system in the Ministry of Defense and the Armed Forces of Ukraine is informational intervention in the consciousness (subconsciousness) of certain target audiences. Such audiences include the leadership and personnel of the troops and the population: a) their own state - in order to maintain their mental state, protection and rehabilitation; b) the enemy - in order to make changes in behavior and (or) worldview, which undermine their moral and psychological state. The place of information-psychological influence is determined by the nature of the task, which is performed not only at the level of the governing body, but in each link of the entire cybernetic circuit of public administration in the military sphere.

Keywords: public administration; information support of the system of public administration at the Ministry of Defense of Ukraine and Armed Forces of Ukraine; information-psychological influence. 